\title{
Biodiversity and Livelihood of the Pangre Jhalas Wetland, Morang District, Nepal
}

\author{
Puspa Lal Pokhrel \\ PhD Scholar, Central Department of Geography \\ Tribhuvan University, Kathmandu
}

\begin{abstract}
There are different wetland ecosystems, different resources, diversity of environment and habitat, and diversity of resource user groups in a region. Local communities exploit these resources and incorporate them into their livelihood strategies. Among these biological diversities, fish are most important and most noticeable wetland resources because they pass through markets and have a recognized role in food supply. Indigenous communities depend on exploiting wetland fisheries. Since past few years, wetlands are degrading rapidly. Poor indigenous communities still relay on catching fish. These communities have characterized by unsuitable living conditions, low level of education, lack of skills and assets and inadequate services which would permit diversification of their livelihoods. We can notice such peculiar activities around the Pangre Jhalas wetland.
\end{abstract}

Key words: wetlands, wetland activities, threats, fish, biodiversity

\section{Introduction}

Wetland is an area consisting of soils that is saturated with moisture, such as swamp, marsh and bogs, fens, and lake. Wetland represents landmass soaked with water due to high water table because of the presence of ground water, springs, and inundation.

The simple definition of wetland is an area where land and water meet .The area may be wet for all or just part of the year and will have distinctive soils and plant communities (SAEFL 2004) Wetlands are river ponds, lakes, marshlands and swamps and agricultural lands which come under water for several months. The term wetlands are known as 'Simsar' in Nepali, which is composed of two words, such as 'Sim' is derivative from Persian word 'Sih' referring to low grade land, not for suitable for cultivation. 'Sar' is a Sanskrit word meaning 'water'. Thus Simsar can be interpreted as land with water .Simsar means different things to different people. There are fifty different definitions of wetlands in the world (WWF 2008) and over twelve terminologies of Simsar in Nepal (Bhandari 2009).

Ramsar Convention Bureau-1971 has defined wetlands broadly including areas of marsh, fen, peat lands or water whether natural or artificial, permanent or temporary, with water that is 
static or flowing, fresh, brackish, or salt, including areas of marine water the depth of which at low tide does not exceeds six meters"

According to the national wetland policy 2003 of Nepal, wetlands denote to perennial water bodies that originate from underground sources of water or rains. It includes swampy areas with flowing or stagnant fresh or salt water that are natural or man-made, or permanent or temporary. Wetlands also mean marshy lands, riverine flood plains, lakes, ponds, water storage area and agricultural lands.

The encyclopedia Americana 1996 defines marsh, as a wetland covered with low growing emergent vegetation such as cattails, rushes or other grass like plants. Marshes vary from backyard-size, wet-weather, soggy places to extensive, coastal plain areas, many of which are several miles wide. The term marsh often overlaps in general usage with bog and swamp. Bogs are usually wetter than marshes and have thick beds of peat and mats of floating vegetation.

Status of wetlands is often changing due to physical environment, cultural views of the people and anthropogenic pressure as well as scale of utilization. Among the resources, wetland ecosystems are highly being influenced by human interventions. Since 1900 over half of the world's wetlands may have disappeared. The United States alone has lost nearby $54 \%$ of its original wetlands, which were converted into agricultural land and urban area development. The total area and condition of tropical wetlands are still unknown, but the available evidence suggests that the pattern of wetland conversion in developing countries may be similar to that of the United States (Barbier 1992). In Nepal, status of wetland has been changed. For instance, from 1971 to 1991, most wetlands have been transferred into an agricultural land, urban development and other development activities.

In Nepal, wetlands are considered as fertile lands for agriculture and are rich from the point of view of biological diversity. The wetlands provide habitat for several species of wildlife and lie within various ecosystems of mountain and lowland plains. Swampy rice fields, water logged area and ponds are also understood as wetlands in Nepal.

In the past, wetlands were considered with hostile contempt and disdain. Only negative aspects were highlighted neglecting wetland values and functions. They were considered wasteland, desolation useless fiver-ridden, good for nothing, etc. and regarded the reservoir of diseases. The purview of people's hatred can be found even in the expressions such as "bog down", "swamp with" "get stuck in a quagmire", "mud splashing" etc. Wetlands were also called "Kalapani", "home of malaria", an unhealthy place where culprits are sent for punishment. Thus, the traditional concept of wetlands is one of the inaccessible waterlogged swamps that harbor disease carrying mosquitoes, poisonous snakes and harmful insects (Bhandari 2006).

Wetlands represent a transition zone between terrestrial and aquatic systems with diverse ecosystems such as quagmire, marshes, oxbow lake, swamps and flood plains. The different wetlands vary widely in ecosystem attributes including characteristics like biota, species richness, productivity and the amount of organic matter accumulating in the sediment. This, in turn, attracts a varied population of aquatic fauna and birds in great numbers. Several of them are resident, while a good many of them are migratory. Wetlands also act as very good 
habitat for development of nursery grounds of shell fishes, crabs and other fauna. Stabilization of sediments is also an inherent value of the coastal wetlands.

\section{Concept}

A great deal of explanation is found in the Vedas about the wetland biodiversities and aquatic animal, mentioning crocodile, crabs, fish, water birds, and greater adjutant. The description of the wetland as the means of livelihood is clearly mentioned in the Vedas. In the Rigveda and Atharva Veda, it is also mentioned that the livelihood of Majhi (Dhiraj = fisherman) is dependent on fishing and this ethnic group 'Majhi' usually dwell on the areas nearby the wetlands. In this way, the ancient saints or sages have been found to have good knowledge about the utility of wetland regions like lake, marsh, water resources etc.

Lakes (oxbow, tectonic and glacial) marshes, swamps, streams, rivers, reservoirs, holies are important scenic features of landscape. They are omnipresent in nature. Water, being their bloodstream, binds all these features together into a collectivity, which we call wetland. Wetland is the lifeline of any ecosystem. Wetlands are the most important source of water and biomass production which are essential for the survival of living beings on the earth. Natural wetlands perform many important functions for humankind - storm prevention, flood and water flow control, nutrient and waste absorption and so forth. Wetlands can also be used for recreation and water transport, and their diverse resources can be directly exploited for fishing, agriculture, medicine, tourism, energy (peat, hydro-power), wildlife products, wood product and water supply. When properly measured, the total economic value of a wetland's ecological functions, its services and its resources may exceed the economic gains of converting the area to an alternative use.

Wetlands have played critical role in the development of human society. For thousands of years, rural communities have relied upon their fertile soils to grow crops, grazed livestock on their rich pastures, fished their productive waters and harvested a diversity of products. In Nepal, the indigenous communities had begun to first settle around the major wetlands area of Jhapa and Morang. These wetlands act as a major source of livelihood for thousands of people living in the area. Fishe are one of the products of the wetlands on which indigenous ethnic communities relay heavily. Hundreds of indigenous households particularly of Dhimal, Satar, Rajbangsi, Meche, Godi and Musahar extract substantial fish resource from the wetlands. Besides fish, shell, Ghungi, crab and mat weaving (from cattail and toad rush) are other major source of income from wetlands. This paper deals with the species diversity, use of wetland resource and its contribution to livelihood of local people

\section{Methodology}

This study is based on primary data collected through household survey and focus group discussion during January 2010. Pangre Jhalas wetland where Dhimal community lives, was selected,. Mostly elders were interviewed. The questionnaire survey was done in the morning and the evening. Focus group discussion was done with the selected Dhimal community and other castes such as Brahmin and Chhetri who are involved in fishing in the wetland. To find the wetland faunal diversity, fishes collected by the local fisherman were observed at the time of fishing. Their fishing net was also used to collect sample from different sites of the wetland. 
Direct observation was done in the morning and evening to collect information on the wetland birds. All 45 Dhimal households of the wetland lying in the Hasandaha VDC were covered for questionnaire survey.

\section{The Study Area}

Pangre Jhalas wetland is located in Hasandaha VDC of Morang District. Located along the west bank of the Bakraha River, it is extended between 260 35' $\mathrm{N}$ and 870 36' $\mathrm{E}$. The elevation of the wetland ranges from 94 masl at the south point to 98 masl to the northern point.

The wetland is elongated from north to south. The length is 526 meters and average width is 25 meters. The width is not equal measuring $20 \mathrm{~m}$ in the north, $25 \mathrm{~m}$ in the middle and $22 \mathrm{~m}$ in the south. It is surrounded by cultivated land to the west and the Bakraha River to the east. Wetland depth varies from 1-3 m during the summer to $60 \mathrm{~cm}$ to $2 \mathrm{~m}$ in the winter. The wetland is a shallow oxbow lake type surrounded by marshes and meadows and tropical reeds (Saccharum spontaneum), thatching grass, rushes, and cattail (Typha elephantine). Pangre Jhalas is a small, but eutrophic (most productive) wetland with marshes and rice paddies in the Holi margin and floating aquatic vegetation and degraded pasture land on the south east shore.

It is drained by Bakraha Khola. Most part of this wetland is subjected to flooding during the monsoon season. In the east of the Bakraha River, Sunga Manglabare road is constructed, where people and two wheels vehicles run.

As the wetland lies in the Tarai, it has tropical monsoon climate, which is very hot in summer and warm in the winter. The average annual rainfall is $200-250 \mathrm{~cm}$. About 90 percent of the total rainfall occurs during the monsoon period, from mid-June to September. In winter, the area receives a small amount of rainfall carried by the south westerly winds (winter monsoon) from the Arabian Sea. Average temperature is 24 Celsius. The maximum temperature of hottest months (June-July) is 40 Celsius and minimum temperature falls to 10 Celsius.

\section{Fish and Livelihood of Indigenous Communities}

Wetland is the source of water. Water is life, means of livelihood and culture is the essence of human life. The relation between wetland and livelihood or human life is inextricably linked. Wetlands and human life or wetland activities enjoy profound inter-relations ever since the origin of life.

Different types of fish live in the wetlands. But due to shallow waters which are warmer and hold less oxygen, thus limited fish species are found in the wetlands. Wetland must also have permanent deep water for fish survival. Common fish species include many of the minnows, sunfish, and bass, as well as nuisance fish like carp. Some fish, such as sunfish and catfish, make extensive use of wetland shallows as nesting areas during the spring season. Bass, on the other hand, use submerged aquatics to lay their eggs upon it. A common misunderstanding among landowners is that cold water species, such as trout, live in their wetland. Trout may survive for a time, but cannot withstand in the warmer waters during summer. Fish can be an important component to control insect pest depending upon the wetland. Mosquito fish controls mosquito larvae that live in warmer water. 
Tarai region harbors the highest number of fish species among all the climatic zones and physiographic region within the country because the wetlands of Tarai are eutrophic (most productive) in nature (Sah 1997) so, there is a close relationship among wetland, fishes and Dhimals, the indigenous community of this area.

Pangre Jhalas wetland acts as a major source of livelihood for thousands of people living in the area. Fish is one of the main products of this wetland on which indigenous ethnic community rely. Most of indigenous people such as Dhimal, Satar, Musar and Godi extract substantial fish resources from Pangre Jhalas wetland. Besides fishing, mat weaving from cattail (Typha elephantine) is another source of income from wetlands. Thatching grass is collected from the wetland for roofing every two years. The grass over and above the use is sold to nearby villagers.

\section{Wetland Products as a Major Source of Nutrient}

Dhimal communities define or understand wetland as the sufficient source of cattail, toadrush, fish and wetland fauna. For them it is the place where man can drown up to neck if they enter, narrow field even to plough, impossible to plant paddy and remains water at least nine months. They take such kinds of paddy fields, small ponds, holies ,Daldals, Jalthal as wetlands where they can find lesser adjutant(Bhundiphor Garud= Leptoptilos Javanicus) and enough waterfowls.

The majority of Dhimal people are depended on wetland for nutrients. Wetland product is a main source of nutrient because these products are cheap and easily available. Fish, shell, ghungi, crab, wetlands birds and some wetland vegetables like as water cress (Kanchi Saag), swamp cabbage (Karmi Saag), sweet flag (Bojho) are product of wetlands. Among them fish is the major product of wetland. The survey showed that all households used to catch fish and Ghungi (beetle like snail) and consume. In addition, crab, shell and wetland birds are also taken as nutrients (Table 2). Crab is a major source of calcium for Dhimal community. It was found plenty in rainy season before 1990. Nowadays, it is diminishing, due to the haphazard and high quantity use of agro-chemicals by peasants to control crop diseases and pests. The crab constructs the hole in manmade ridge of a rice field and live in the hole. The peasants were mostly suffering from crab hole while irrigating the paddy fields and they began to put powerful pesticide (phorate) in the hole frequently. These harmful activities are in practice before some time and still continuing. These activities have been affecting all the aquatic faunal diversity. Therefore, wetland fauna is decreasing rapidly, along with changing food habit of Dhimals. Before 1990, most households used to consume fish daily, but at present, only 14 households are taking fish daily as curry. Table 1 shows the food habit of Dhimals in regard to fish in their diet.

Table 1: Fish as major source of diet

\begin{tabular}{lcr}
\hline Household's food habit & Frequency & Percent \\
\hline Daily & 14 & 31.11 \\
Weekly & 6 & 13.33 \\
Twice a week & 2 & 4.44 \\
monthly & 8 & 17.77 \\
rainy, season & 14 & 31.11 \\
weekly in winter, & 1 & 2.22 \\
\hline Total & 45 & 100.0 \\
\hline
\end{tabular}

Source: Field survey, January, 2010 
Table 2 depicts the number of households by wetland products.

Table 2: Wetlands products source of nutrients

\begin{tabular}{lcc}
\hline Item of wetland product & Wetland product user family & No wetland product user family \\
\hline Fish & 45 & 0 \\
Shell & 36 & 9 \\
Ghungi & 45 & 0 \\
Crab & 44 & 1 \\
Wetland bird & 35 & 10 \\
\hline
\end{tabular}

Source: Field survey, January, 2010

Dhimals have diverse wetland economic activities to sustain their livelihood. Agriculture, fishing, mat weaving from cattail, collecting crab and shell, foreign employment and alcohol production are the major economic activities of Dhimal communities. In Pangre Jhalas wetland, more than one third households are fully depended on wetland for surviving their livelihood. Among them majority of households are engaged in wage labour and mat weaving from cattail and eleven percent households are engaged in waging and fishing. On the other hand, landless households are engaged in wage work, fishing and mat weaving activities. Those households, who have less than 0-5-0 bighas of agricultural land, are involved in waging and fishing. One third households collects wetland products to sell in the market for money and more than two third of households collects wetland products for their domestic use. In the past, fishing was an important economic activity in this surrounding area. At present fishing activities has declined due to degrading of wetlands.

Table 3: Occupational Structure of Dhimal Community

\begin{tabular}{lcccl}
\hline Occupation & $\begin{array}{c}\text { No of } \\
\text { households }\end{array}$ & $\begin{array}{c}\text { Land holding } \\
\text { size (bigha) }\end{array}$ & $\begin{array}{c}\% \\
\% \text { Major source of } \\
\text { income }\end{array}$ \\
\hline $\begin{array}{l}\text { Waging, fishing and mat weaving } \\
\text { from cattail }\end{array}$ & 10 & Landless & $22.00 \begin{array}{l}\text { Fish and mat } \\
\text { selling }\end{array}$ \\
Waging and fishing & 5 & Below0-5-0 & 11.11 Fish selling \\
Agriculture and alcohol production & 6 & $0-6-0$ to 0-10-0 & 11.11 Alcohol selling \\
Agriculture and foreign employment & 8 & $1-0-0$ to 1-5-0 & 17.75 Remittance \\
Agriculture and teaching & 1 & $1-5-0$ to 2-0-0 & 22.21 Teaching \\
Agriculture and fishing & 16 & $2-0-0$ to 4-0-0 & 35.00 Agriculture \\
\hline Total & 45 & & 100.0 & \\
\hline
\end{tabular}

Source: Field survey, January, 2010.

\section{Wetlands and Faunal Diversity}

Eastern Terai falls within the peninsular Indian division of the Indo-Malayan realm (Corbet and Hill, 1992). Wetlands support several species of fauna; most of them are endemic or globally threatened. Nepal's wetlands support significant species diversity and population of globally threatened fauna. According to 2003 IUCN red list, 123 globally threatened faunal species occur in Nepal, of which, 42 species (34\%) are found either in freshwater biomes or are also significantly dependent on wetlands. Available information suggests that most of globally 
threatened wetland species found in Nepal are dependent on Terai wetlands. There are 861 bird species found in Nepal, 193 (22.5\%) are known to be dependent on wetlands. According to IUCN red list of 2003, 12 globally threatened species that are wetland dependent. Among them Lesser Adjutant (Leptoptilos Javanicus) is in vulnerable condition (IUCN 2004), which is found in surrounding areas of Pangre Jhalas wetland. The author counted 31 Leptoptilos Javanicus (Bhundiphor Garud) near Sunbarsi wetlands of Bhahundov of Govindapur VDC. Of which 16 are chicks and 15 are adult pairs. There are eight nest on the silk cotton tree (Simal tree).The population was counted by point count method (Direct observation method). The observation was conducted in January.

Table 4: Fish diversity in Pangre Jhalas Wetland

\begin{tabular}{lcr}
\hline Type of fishes & No. of households & Percent \\
\hline Bam (Anguilla bengalensis) & 45 & 100.00 \\
Hile (Channa stewarti) & 44 & 97.77 \\
Mangri (Clarias batrachus) & 43 & 95.55 \\
Sidra (Punitus panctatus) & 44 & 97.77 \\
Gaichi (Macrognathus aculeatus) & 36 & 80.00 \\
Jhinge (Palaemon malcolumsoni) & 44 & 97.77 \\
Paiya (Progastus) & 33 & 73.33 \\
Deri (Esomus dendricus) & 43 & 97.77 \\
Pothi (Puntius sophore) & 43 & 97.77 \\
Buwali (Wallago attu) & 14 & 31.11 \\
Garai (Channa puntatus) & 10 & 22.22 \\
\hline AndhaBam (Amphipnous cuchia) & 5 & 11.114 \\
\hline
\end{tabular}

Source: Field survey, January, 2010

The Terai region harbors highest number of fish species among all the physiographic zones within the country. Altogether $154 \mathrm{spp}(83 \%)$, which represent all the 11 orders of fish reported from Nepal, are found in the Terai (Bhandari1995). A study of fish fauna found in the Koshi River was undertaken by Menon (1949) which reported 52 species of fish from the river in both Indian and Nepalese territory. In recent study, 83species comprising 24 family were recorded from 13 different sites of the Koshi Tappu and the surrounding area (WMI/IUCN-Nepal1994). In Pangre Jhalas wetland and its surrounding area there are reported 12 species of fish. They are bam macha, hile, sidra, gaichi, paiya, deri, pothi, mangri, buwali, jhinge, garai, andha bam etc. The indigenous fish stocks have been declining due to over fishing and harmful fishing practices. Soul and singi fish have disappeared from this wetland. Development work like Bakraha embankment has major impacts on wetland ecology and aquatic flora and fauna.

\section{Birds}

Panger Jhalas Wetland provides valuable habitat for some of birds in the eastern Terai. Some birds are obligate wetland species that require wetlands for their survival. Others are facultative species which may use wetlands, but do not require them for their survival. Waterfowl are the group of birds most people associate with Wetlands. Waterfowl include the ducks, geese, and swans. Dabbling ducks use shallow areas of restored wetlands, where they can tip up and feed off the bottom. Divers need deeper water in which to dive and feed. Geese are grazers and will 
feed on pastures and croplands near restored wetlands. Swans are surface feeders, but also feed on underwater vegetation. These birds feed on exposed mudflats, including those which occur as a result of summer drawdown. Amphibians are found in the shallows. Water deeper than about 18 inches isw not used much by wading birds. Some birds like Hutitaun, Simkukhura, heron, and common crane require emergent vegetation or shrubs to nest. Lesser Adjutant and some wading birds depend on invertebrates like fish and frogs for their food found on wetlands and agricultural fields.

\section{Floral Diversity}

Marshes are those wetlands where the land remains under water throughout the year. The depth of water is shallow. In these physical conditions, reeds, grasses and sedges grow very well. Marshy plants and their associated habitat provide important breeding and staging areas for resident and endemic bird. The aquatic body of Pangre Jhalas is represented by aquatic angiosperms like cattail (Typha angustifolia), reeds, sedges, water hyacinth (Eichhornia crassipes), and sweet flag (Acorus calamus). Beside these, submerged floating and emergent vegetation are also available. There are over 12 species of floating hydrophytes; they provide a nesting habitat for birds such as the pheasant- tailed Jacana, Bronze winged Jacana, and Purple Moorhen (Sankhala, 1990). Submerged hydrophytes include suspended or rooted submerged species, 16 of which occur in the oxbow lakes of the Terai. A number of algae species (chara sp., nitella sp., spirogyra sp.) can also be found. These submerged hydrophytes provide food for fish and a habitat for large numbers of invertebrates (especially crusta ceans) and some birds such as pintails (Anas acuta) (IUCN 2004) Emergent plants share common hydrophytic characteristics and are highly sensitive to seasonal fluctuations in the water level, which generally occupies the water margin of the perennial water bodies, becomes submerged when there is a rise in water level during the wet season .Due to seasonal fluctuations, the new shoots of aquatic vegetation down out and become decomposed into the water after some time, enriching wetland with organic matter. Besides above mentioned vegetation, pani unyou (Hydrilla verticillata), karmi saag (Ipomoea aquatica, banmara (Chromolaena odorata ( L.) King and Robin), niguro (Dryopteris cochleata (Don) C.chr), Kans (Saccharum spontaneum L.) are also found.

\section{Wetlands and Grazing}

Open grazing is considered to be the cheapest way of feeding livestock. Peasants have been taking their domestic animal to graze in different places during different seasons along the Bakraha wetlands; from the beginning of settlement. In a typical village of the Tarai, livestock graze on public land and road side between June and September, on the bounds of the field during September to December and in harvested fields from December to June. The trend is different in the villages near Koshi Tappu wetlands, where in addition to these places, about $95 \%$ of the households take their livestock's to graze either in the grassland or forest of the reserve or in the marshes. Marshes are the main grazing site for livestock (Sah 1997).

Dhimal households have small number of livestock population. Other casts (Brahmin, Chhetri) households have greater number of livestock population. The Pangre Jhalas and Bakraha wetlands are favorable grazing site for livestock of Hasandaha. The field observation shows that the area is not only a grazing site for livestock from adjoining villages of Hasandaha but also for those from other villages. The herders of western part of Itahara and Rajghat and southern part 
of Pathari V.D.C. grazed their livestock in these wetlands. Intensive grazing in the surrounding environment is destroying the habitat of several bird species.

\section{Threats of Wetlands}

There are some threats to wetlands in eastern Terai. Morang district is no exception .The threats are natural and cultural process. These are associated with:

- Devastation and shrinking of wetlands: wetlands are declining and shrinking by human activities and sedimentation of Bakraha River, which carries huge amount of sediment. The highest sediment concentration is associated with high flooding times.

- Mutation of wetland in agricultural land: The transformation of marshes and oxbow lake to agricultural land particularly paddy fields, is being continued to increasing around urban periphery and populated rural area. Pangre Jhalas wetlands has been draining often by water pumps to provide irrigation since mid of 1990s or to collect fish, and it drives to rapid shrinking out.

- Overgrazing: Open grazing is common in the rural areas of eastern Terai. There is still a traditional socio cultural and agricultural practice. Grassland areas are being limited in Teri due to urbanization process, development of new small market centre's and rapid population growth. Remaining limited grasslands around the wetlands are under high pressur of heavy grazing. In the Himalayan region, a pasture grazing is a seasonal threat (IUCN 2004). But those marshes and oxbow lakes, which are located in Morang and Jhapa are continuously facing threats all over the year. Over grazing activities is common phenomena surrounding wetland environment of Morang and Jhapa which leads to disturbance in bird habitat through the ruination of the nests of ground dwelling species like Hutitaun and Simkukhura.

- Weak land registration policy: Most of the wetlands were not registered before 1980s. They were possession under the government. They are called Ailani Jagga (barren land or open land not registered yet in a personal name) by the government. When population increased rapidly urbanization process also increased in the same ratio, the wetlands are registered by land exploiters in personal name with the help of land revenue officers. First of all, land exploiter filled the wetland to transfer the land into the agricultural land then register as personal assets. The weak registration policy is a cause of wetlands degradation.

- Lack of protection law to conserve private wetlands: There is no conservation law for private wetland. The owner can easily modify his wetland according to his interest. They are unknown about importance of wetlands. Therefore private wetland is diminishing rapidly and is converted to agricultural and residential land.

\section{Conclusion}

In the past, Pangre Jhalas wetland had huge area, which now is shrinking and its ecology is degrading rapidly. The wetland is being transformed into agricultural land due to encroachment of human settlement. The local land owners have filling the wetlands with soils. On the other hand, some communities around Pangre Jhalas, Bakraha and adjoining wetlands areas remain fully dependent on their surrounding wetlands products as the base for their livelihood. Their wetland based economic activities are at high risk and their food habits are changing continuously. Over fishing activities affected the size of fish population. Over collecting of cattail and other 
wetlands vegetation also affected the floral diversity. Unsustainable draining method is used to collect all the fish and aquatic products which cause the loss of feeding and breeding sites of aquatic and faunal diversity. These draining activities affect habitats to undergo ecological change towards dry land. Harmful fishing methods (poising and electrocute) used by outsider fishermen for mass killing reduced aquatic faunal diversity. It also affects the food chain of the ecosystem. The general view of the users of the wetlands is that it must be protected. Especially the older users of Dhimals are convinced that the environment of the surrounding area has deteriorated and that steps have to be taken to protect it from the further damage.

\section{References}

Bhandari B.B. (2009), Wise Use of Wetlands in Nepal. BANKO JANAKARI. A Journal of Forestry Information for Nepal. Department of Forest Research and Survey (DFRC). Ministry of Forests and Soil Conservation, Government of Nepal: pp 10-17.

Barbier, E.B. (1992), Sustainable Use of Wetlands Valuing Tropical Wetland Benefits: Economic Methodologies and Applications. The Geographical Journal Vol.159,No 1: pp22-32) Royal Geographical Society London.

Corbet, G.B. and Hill (1992), The mammals of the Indo-Malayan Region. Oxford University Press, Oxford. London.

Hoogvorst, Anneke (2003).Survival strategies of people in a Sri Lankan Wetland: Livelihood, health and nature conservation in Muthurajawela.Ph.D. Thesis,Wageningen University.

Husak, S. and J. Kvet.(1990), Role of macrophyte in ponds and wetlands.

IUCN (2004), A Review of the Status and Threats to Wetlands in Nepal. IUCN, Wetlands and Water Resource Programme, Blue Series. IUCN Nepal Country Office

IUCN, (1996), Pan AFRICAN symposium on Sustainable Use of Natural Resources and Community Participation. Harare, Zimbambwe, June 24 - 27, 1996.

Rajbanshi, K.G. and Gurung, T.B. (1994), Wetlands and fisheries: prospects and constraints. Safeguarding wetlands in Nepal. Bhandari, B. Shrestha and John McEachern (ed). Proceeding of the national workshop on wetlands management in Nepal. IUCN Nepal.

Sah, J.P. (1997), Koshi Tappu Wetlands: Nepal's Ramsar Site.The International Union for Conservation of Nature and Natural Resources. IUCN Country office ,Kathmandu, Nepal

Shankhala, K. (1990), Gardens of God: The water bird sanctuary at Bharatpur. Vikas Publishing House Pvt.Ltd.

Shrestha, J. ( 1992), The role, scope and importance of natural water resources for increased fish production in Nepal. In Pantha et.al. (eds).Proceedings of the workshop on Human Resources Development in fisheries Research ,1-3 April, Kathmandu, Nepal: Fisheries Development Division.

Turner, K. (1991), Economics and Wetland Management. Ambio 20 pp59-63

WWF (2004, The Economic Values of the Worlds' Wetlands. Kirsten Schuyt and Luke Brander (ed), Gland, Amsterdam. 